\title{
Cryofibrinogenemia with Polyarthralgia, Raynaud's Phenomenon and Acral Ulcer in a Patient with Graves' Disease Treated with Methimazole
}

\author{
Keita Hosoi, Shigeki Makino, Yuriko Yamano, Masako Sasaki, \\ Toru TAKeuchi, Sadaki SAKANE and Nakaaki OHSAWA
}

\begin{abstract}
Cryofibrinogenemia is a cryopathy in which hypersensitivity to cold is a prominent feature. Cryofibrinogenemia developed in an 18-year-old Japanese female patient during methimazole therapy for Graves' disease. She developed cryopathy (livedo reticularis, Raynaud's phenomenon and acral ulcer) and polyarthralgia during methimazole therapy, and we detected cryofibrinogen in her plasma. Her symptoms resolved after administration of prostaglandins and anticoagulants. Several reports indicate that methimazole therapy induces autoantibody-related disease. In the present case, we cannot exclude the possibility that methimazole therapy contributed to the cryofibrinogenemia.
\end{abstract}

(Internal Medicine 36: 439-442, 1997)

Key words: cryofibrinogen, cryopathy, livedo reticularis

\section{Introduction}

The symptoms of cryopathy, a condition in which hypersensitivity to cold is a prominent feature, are livedo reticularis, Raynaud's phenomenon, purpura, and skin ulcer. This condition is seen in various diseases including cold urticaria, paroxysmal cold hemoglobinuria, cold agglutinin syndrome, cold hemolysin syndrome, cryopathy associated with collagen disease, Raynaud's disease, cryoglobulinemia, and cryofibrinogenemia. In these diseases, the cryofibrinogenemia is characterized by cryoprecipitable protein in plasma but not in serum. This is not an uncommon condition, although most cases of cryofibrinogenemia are asymptomatic. In symptomatic cases, cold intolerance, purpura, skin ulcers, livedo reticularis, arthralgia and Raynaud's phenomenon have been reported as symptoms of cryofibrinogenemia (1). We report a case of Graves' disease which developed during methimazole therapy and presented with cryofibrinogenemia with arthralgia and cryopathy (Raynaud's phenomenon, acral ulcer, livedo reticularis).

\section{Case Report}

An 18-year-old Japanese woman who presented with Ray- naud's phenomenon, acral ulcer and polyarthralgia was admitted to Osaka Medical College on March 1, 1995. She had visited our hospital because of goiter in April 1992. Her symptoms were hand tremor, body weight loss and low grade fever. Her thyroid function test results indicated hyperthyroidism; the serum levels of thyroid hormones were high, with a free Lthyroxine (FT4) level of $4.5 \mathrm{ng} / \mathrm{dl}$, and triiodothyronine (T3) of $2.8 \mathrm{ng} / \mathrm{dl}$, and the serum thyroid stimulating hormone (TSH) level was suppressed $(<0.1 \mu \mathrm{U} / \mathrm{ml})$. As the TSH receptor antibody test result was positive $(\times 80)$, we diagnosed her illness was Graves' disease. In May 1992 she began treatment with methimazole at an initial dose of $30 \mathrm{mg}$ per day. In January 1994 she developed arthralgia of the bilateral ankles and right elbow with purpura on both lower legs. Rheumatoid factor was negative, and no deformity of the joints was found. Treatment was started with acetylsalicylic acid (1.5 mg daily) and prednisolone (15 mg daily). Her symptoms were slightly improved, but in January 1995, when the dose of prednisolone was reduced to 5 mg daily, the symptoms worsened again. Moreover, in February she developed livedo reticularis, Raynaud's phenomenon and acral ulcer of the left big toe, and she was readmitted to our hospital.

On admission, her weight and height were $47 \mathrm{~kg}$ and $160 \mathrm{~cm}$, respectively, and her blood pressure, pulse rate, and body

From the First Department of Internal Medicine, Osaka Medical College, Osaka Received for publication October 3, 1996; Accepted for publication March 18, 1997

Reprint requests should be addressed to Dr. Keita Hosoi, the First Department of Internal Medicine, Osaka Medical College, 2-7 Daigaku-cho, Takatsuki, Osaka 569 
temperature was $120 / 72 \mathrm{mmHg} ; 75 / \mathrm{min}$, and $37.2^{\circ} \mathrm{C}$, respectively. The respiration rate was $12 / \mathrm{min}$. No signs of anemia, jaundice, lymph node swelling or goiter were revealed by physical examination. Her heart sound was clear, and auscultation of the lungs revealed no rales. The abdomen was soft and flat. Livedo reticularis was observed on both lower legs. Acral ulcer was observed on the left big toe (Fig. 1). Both ankle joints were swollen, warm and painful, and the right elbow joint was painful but not swollen. These joints presented no deformity on the X-ray image. The chest X-ray findings on admission were normal.

The laboratory data are summarized in Table 1a. The urinalysis results were normal, the erythrocyte sedimentation rate was $20 \mathrm{~mm} / \mathrm{h}$, the serum C-reactive protein level was $3.24 \mathrm{mg} /$ $\mathrm{dl}$, the white blood cell count $9.0 \times 10^{3} / \mu \mathrm{l}$, hemoglobin $11.3 \mathrm{~g} / \mathrm{dl}$, hematocrit $35.8 \%$, and platelet count $28.8 \times 10^{4} / \mu$. The serum complement levels were normal, with $\mathrm{CH}_{50}$ of $47.4 \mathrm{U} / \mathrm{ml}, \mathrm{C} 3$ of $86.14 \mathrm{mg} / \mathrm{dl}$, and C4 of $30.60 \mathrm{mg} / \mathrm{dl}$. The prothrombin time and active partial thromboplastin time were normal, but the serum fibrinogen level was elevated to $420 \mathrm{mg} / \mathrm{dl}$. Serum protein electrophoresis revealed polyclonal hypergammaglobulinemia, with $\operatorname{IgG}, \operatorname{Ig} \mathrm{A}$, and $\operatorname{IgM}$ of 2,287, 365, and $256 \mathrm{mg} / \mathrm{dl}$, respectively. The thyroid function test profile was that of euthyroidism, with serum FT4 of $1.41 \mu \mathrm{g} / \mathrm{dl}$, serum free L-thyronine (FT3) of $2.14 \mathrm{pg} / \mathrm{dl}$, and TSH of $0.11 \mu \mathrm{U} / \mathrm{ml}$. Anti-thyroidstimulating hormone receptor antibody was positive with a high titer $(30 \%)$, and anti-microsomal antibody was also positive $\left(\times 160^{2}\right)$. The test for antithyroglobulin antibody was negative, but that for anti-nuclear antibody (ANA) was positive $(\times 640)$ with a speckled pattern. No other autoantibodies, such as antiDNA antibody, anti-Sm antibody, anti-RNP antibody, anti-SSA and SS-B antibodies or rheumatoid factor were detected. Lupus anticoagulant (LAC) and anticardiolipin antibody were also negative. The cold agglutinin reaction and the serological test for syphilis were negative. Her serum was negative for cryoglobulin, but cryofibrinogen was detected in citrated plasma. In the detection of cryofibrinogen, we used her citrated plasma, and samples were centrifuged at warm temperatures with subsequent cooling to $4^{\circ} \mathrm{C}$. As Fig. 2 shows, the precipitate was visible at $4^{\circ} \mathrm{C}$ but it dissolved upon warming. The cryocrit was $18 \%$.

Histological examination of a specimen from the left big toe ulcer showed dilatation in the majority of the superficial and deep dermal blood vessels with necrosis of the epidermis and dermis. Examination by laser Doppler flowmetry (2) revealed reduced blood flow of the toes, especially the left big toe, under cold conditions (Table 1b). As these findings revealed hypersensitivity to coldness, we made the diagnosis of symptomatic cryofibrinogenemia.

Treatment was started with prostaglandin E1 (PGE1, Limaprost altadex, opalmon ${ }^{\circledR}, 30 \mu \mathrm{g} /$ day) and a low dose of acetylsalicylic acid (aspirin ${ }^{\circledR}, 81 \mathrm{mg} /$ day). Her symptoms resolved on day 32 after the start of the additional drug administration (Fig. 3).

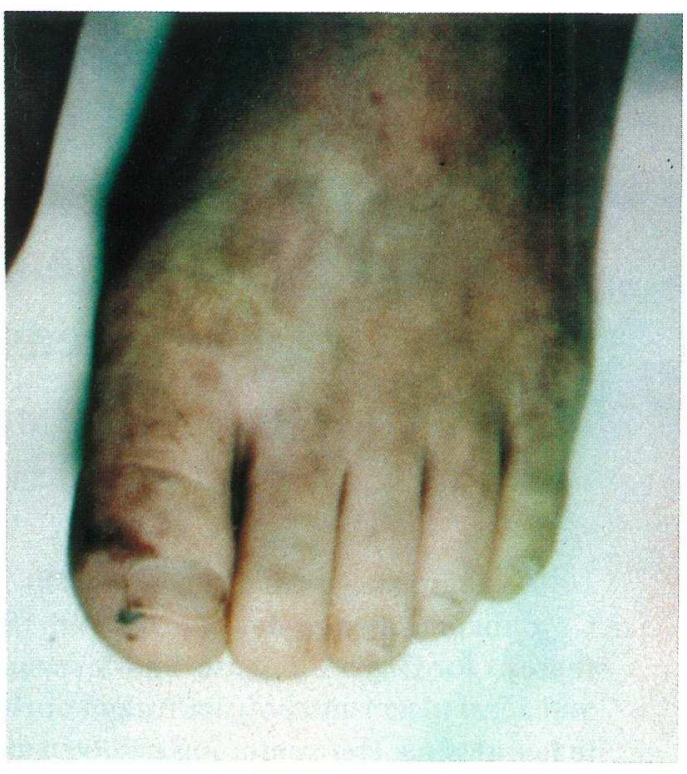

Figure 1. The left lower leg is showing livedo reticuralis and the first toe is showing acral ulcer.
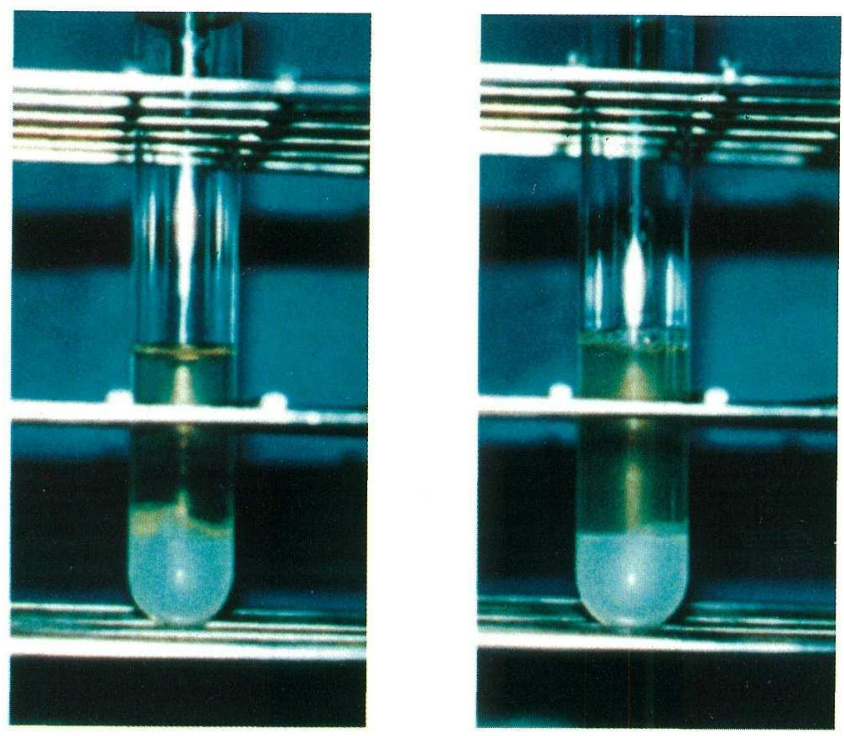

Figure 2. Photographs of the plasma cryoprecipitate results for citrated plasma at $4^{\circ} \mathrm{C}$ (left) and at $37^{\circ} \mathrm{C}$ (right). In the tube on the left there is a precipitate, which dissolved upon warming on the white matter. In the tube on the right there is no precipitate on the white matter.

\section{Discussion}

In 1955 Korst and Kratochvil first identified a protein fraction that precipitated under cold environment and melted by heating in the plasma from a lung cancer patient with thrombophlebitis migrans (3). Theirs was the first report concerning 
Methimazole-Induced Cryofibrinogenemia

Table 1a. Laboratory Findings on Admission

\begin{tabular}{|c|c|c|c|}
\hline Urinalysis & Normal & Serological test & \\
\hline ESR & $20 \mathrm{~mm} / \mathrm{h}$ & CRP & $3.24 \mathrm{mg} / \mathrm{dl}$ \\
\hline Peripheral blood & & ASO & $<65.0 \mathrm{IU} / \mathrm{dl}$ \\
\hline WBC & $9.00 \times 10^{3} / \mu 1$ & $\operatorname{IgG}$ & $2,287 \mathrm{mg} / \mathrm{dl}$ \\
\hline neut & $67.6 \%$ & $\operatorname{Ig} \mathrm{A}$ & $365 \mathrm{mg} / \mathrm{dl}$ \\
\hline lymph & $19.4 \%$ & $\operatorname{IgM}$ & $256 \mathrm{mg} / \mathrm{dl}$ \\
\hline $\mathrm{RBC}$ & $4.45 \times 10^{6} / \mu 1$ & CH50 & $47.4 \mathrm{U} / \mathrm{ml}$ \\
\hline Hemoglobin & $11.3 \mathrm{~g} / \mathrm{dl}$ & $\mathrm{C} 3$ & $86.1 \mathrm{mg} / \mathrm{dl}$ \\
\hline \multirow[t]{2}{*}{ Platelet } & $2.88 \times 10^{5} / \mu \mathrm{l}$ & $\mathrm{C} 4$ & $30.6 \mathrm{mg} / \mathrm{dl}$ \\
\hline & & $\mathrm{RF}$ & $<25.0 \mathrm{IU} / \mathrm{ml}$ \\
\hline Blood chemistry & & RAPA & $x<40$ \\
\hline Total protein & $7.5 \mathrm{~g} / \mathrm{dl}$ & IgG-RF & $(-)$ \\
\hline Albumin & $51.4 \%$ & ANA & $\times 640$ \\
\hline$\alpha_{1}$-globulin & $4.0 \%$ & Anti ds-DNA Ab & $(-)$ \\
\hline$\alpha_{2}$-globulin & $12.6 \%$ & Anti ss-DNA Ab & $(-)$ \\
\hline$\beta$-globulin & $9.5 \%$ & Anti RNP Ab & $(-)$ \\
\hline$\gamma$-globulin & $22.5 \%$ & Anti Sm Ab & $(-)$ \\
\hline AST & $10 \mathrm{U} / \mathrm{l}$ & P-ANCA & $(-)$ \\
\hline ALT & $5 \mathrm{U} / l$ & Immune complex & $(-)$ \\
\hline LDH & $128 \mathrm{U} / l$ & Anti CL. $\beta_{2} \mathrm{GP} 1 \mathrm{Ab}$ & $(-)$ \\
\hline CPK & $24 \mathrm{U} / l$ & Anti cardiolipin IgG Ab & $(-)$ \\
\hline Glucose & $71 \mathrm{mg} / \mathrm{ml}$ & Anti cardiolipin IgM Ab & $(-)$ \\
\hline BUN & $18 \mathrm{mg} / \mathrm{dl}$ & Lupus anti coagulant & $(-)$ \\
\hline Creatinine & $0.6 \mathrm{mg} / \mathrm{dl}$ & Cold agglutination & $(-)$ \\
\hline $\mathrm{Na}$ & $139 \mathrm{mg} / \mathrm{ml}$ & Cryoglobulin & $(-)$ \\
\hline $\mathrm{K}$ & $4.1 \mathrm{mg} / \mathrm{ml}$ & Thyroid function & \\
\hline $\mathrm{Cl}$ & 104 mg/ml & TSH & $1.8 \mu \mathrm{U} / \mathrm{ml}$ \\
\hline Coagulation study & & FT4 & $1.11 \mathrm{ng} / \mathrm{dl}$ \\
\hline PT & $100 \%$ & TRAb & $20 \%$ \\
\hline APTT & $38.3 \mathrm{sec}$ & & \\
\hline Fibrinogen & $420 \mathrm{mg} / \mathrm{dl}$ & & \\
\hline TAT & $2.27 \mu \mathrm{g} / \mathrm{l}$ & & \\
\hline FDP & $51 \mathrm{ng} / \mathrm{ml}$ & & \\
\hline
\end{tabular}

PT: Prothrombin time, APTT: Activated partial thromboplastin time, TAT: thrombin antithrombin complex, FDP: fibrin and fibrinogen degradation products, AST: aspartate aminotransferase, ALT: aranine aminotransferase, LDH: lactate dehydrogenase, CPK: creatine phosphokinase. BUN: blood urea nitrogen, CRP: C-reactive protein, ASO: antistreptolysin O, RF: rheumatoid factor, RAPA: rheumatoid arthritis particle agglutination, TSH: thyroid stimulating hormone, FT4: free T4, TRab: thyrotropin receptor antibody, ANA: anti-nuclear antibody, Anti-ds-DNA Ab: anti-double-stranded DNA antibody, Anti-ss-DNA Ab: anti-single-stranded DNA antibody, Anti CL. $\beta_{2} \mathrm{GP1}$ Ab: anticardiolipin $\beta_{2}$ glycoprotein 1 complex antibody, ESR: erythrocyte sedimentation rate.

Table 1b. Laser Doppler Flowmetry of Extremities

\begin{tabular}{lcr}
\hline & $4^{\circ} \mathrm{C}$ & $45^{\circ} \mathrm{C}$ \\
\hline Rt. upper extremity & 6.6 & 14.1 \\
Lt. upper extremity & 6.6 & 13.5 \\
Rt. lower extremity & 1.1 & 10.1 \\
Lt. lower extremity & $0.1 \downarrow$ & 4.6 \\
& & $(\mathrm{ml} / \mathrm{min} / 100 \mathrm{~g})$ \\
\hline
\end{tabular}

cryofibrinogenemia. According to the report by Kellett, cryofibrinogenemia was observed in 3.4 to $8.5 \%$ of outpatients (4). Smith and Arkin reported a prevalence of 3\% for cryofibrinogenemia in their hospital patients (5). Thus, cryofibrinogenemia is not an uncommon state. These reports also indicated, however, that most cases were asymptomatic. Zlotnick et al reported that the symptoms of this disease were cutis marmorata, Raynaud's phenomenon, acrocyanosis, acral necrosis, and hemorrhage (1). Most of these symptoms are those of cryopathy. The present patient's symptoms of acral ulcer, livedo reticularis, and Raynaud's phenomenon are compatible with cryofibrinogenemia.

Although this condition may occur in some patients without 


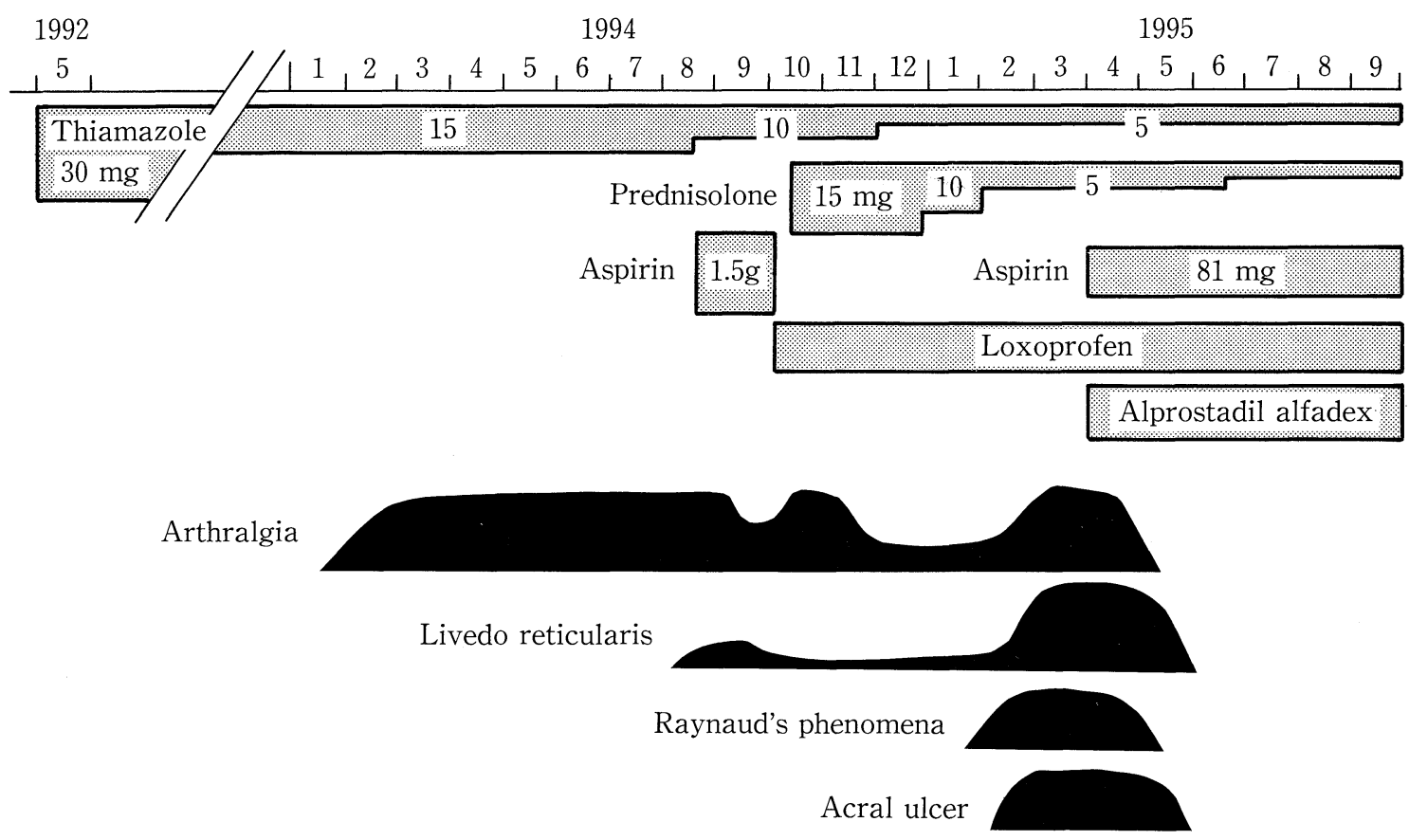

Figure 3. Clinical course of the present case.

underlying diseases, when it is known as essential cryofibrinogenemia, most patients with this condition have it secondary to underlying diseases such as thrombosis, infection, metastatic cancer, macroglobulinemia, Hodgkin's disease, myocardial infarction, and collagen disease. According to Zlotnick et al most symptomatic patients with this disease present either essential or collagen disease-related cryofibrinogenemia (1).

Grave's disease is an organ specific autoimmune disease. There are several reports that methimazole therapy induces autoantibody production. Yoshikawa et al reported a case of insulin autoimmune syndrome induced by methimazole in a patient with Grave's disease (6), and Gemma et al reported a case of LDH-linked immunoglobulin in a patient with Grave's disease treated with methimazole (7). Euler et al reported a case of cryofibrinogenemia in which the cryofibrinogen was composed of fibrinogen and a monoclonal anti-fibrinogen antibody $(\operatorname{IgG} 3 \kappa)$ (8). Therefore, in the present patient, we cannot exclude the possibility that methimazole therapy contributed to the development of cryofibrinogenemia.

The therapy that has been used for symptomatic cryofibrinogenemia includes heparin, warfarin, streptokinase, plasmapheresis, anabolic steroid, and immuno-suppressive therapy (9). In patients with mild symptoms and signs, avoidance of cold exposure may be adequate.

We treated the present patient, who had a severe ulcer on her first toe, with acetylsalicylic acid as an anticoagulant, and prostaglandin as a vasodilator. This patient has been in remission with this therapy. Cryofibrinogenemia should be taken into consideration when making a diagnosis of cryopathy in a patient with Graves' disease treated with methimazole.

\section{References}

1) Zlotnick A, Shahin W, RachmilewitzEA. Studies in cryofibrinogenemia. Acta Haematol 42: 8, 1969.

2) Vegfors M, Tryggvason B, Sjoberg F, Lennmarken C. Assessment of peripheral blood flow using a pulse oximeter. J Clin Monit 6: 1, 1990.

3) Korst DR, Kratochvil CH. "Cryofibrinogen" in a case of lung neoplasm, associated with thrombophlebitis migrants. Blood 10: 945, 1955.

4) Kellett J. Thyrotoxicosis, cryofibrinogenemia, sinutab maximum strength, and purple ears. Ann Intern Med 110: 668, 1989 (letter).

5) Smith SB, Arkin C. Cryofibrinogenemia: incidence, clinical correlations, and a review of the literature. Am J Clin Pathol 58: 524, 1972.

6) Yoshikawa $\mathrm{H}$, Kawai $\mathrm{K}$, Inoue $\mathrm{S}$, et al. Hyperglucagonemia of insulin autoimmune syndrome induced by methimazole in a patient with Graves' disease. Endocrinol Jpn 36: 125, 1989.

7) Gemma R, Suzuki Y, Tanaka I, Taminato T, Yoshimi T, Kanno T. Lactate dehydrogenase (LDH)-linked immunoglobulin in a patient with Graves' disease treated with methimazole. Internal Medicine 31(3): 377, 1992.

8) EulerHH,Zeuner RA, Beress R, Gutschmidt HJ, Christophers E, Schroeder JO. Monoclonal cryoantifibrinogenemia. Arthritis Rheum 39: 1066, 1996.

9) Jantunen E, Soppi E, Neittaanmaki H, Lahtinen R. Essential cryofibrinogenemia, leukocytoclastic vasculitis and chronic purpura. J Intern Med 234: 331, 1993. 